\section{Performance, carcass characteristics and ingestive behavior of steers fed with silages of different maize hybrids}

\author{
[Desempenho, características da carcaça e comportamento ingestivo de \\ novilhos alimentados com silagens de diferentes híbridos de milho]

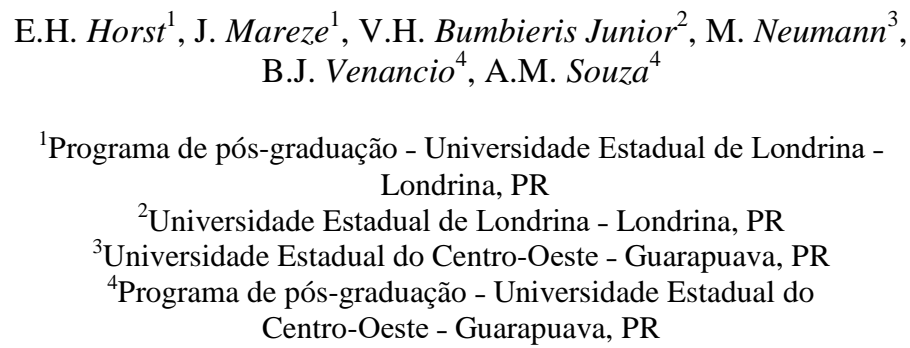

https://orcid.org/0000-0001-8365-5237 B.J. Venancio

https://orcid.org/0000-0002-5614-8229 A.M. Souza

https://orcid.org/0000-0002-0091-7885

\begin{abstract}
The objective of this study was to evaluate the performance, carcass characteristics and ingestive behavior of feedlot steers fed with three maize hybrids: Maximus VIP3, Defender VIP and Feroz VIP. The experiment lasted 112 days, weighing animals four times, every 28 days. The experimental diets were formulated and constituted by maize silage and pelletized ration in a 50:50 ratio (dry basis). Regardless of the hybrid used, there was an increase in the intake of dry matter with the advance in feedlot evaluation period $\left(9.15,9.14,9.35\right.$ and $9.59 \mathrm{~kg} \mathrm{day}^{-1}$, in the first, second, third and fourth weighing, respectively). The type of maize hybrid silage influenced weight gain of animals differently, with a final mean of $1.413 \mathrm{~kg}$ for animals fed with Maximus VIP3, $1,375 \mathrm{~kg}$ for those fed with Defender VIP and $1,184 \mathrm{~kg}$ for those fed with Feroz VIP. The animals fed with Feroz VIP hybrid silage showed higher carcass gain efficiency and were more active in the number of times they went to the feeder. Although the three evaluated hybrids resulted in good animal performance, the carcass characteristics did not change; nevertheless, the hybrid Maximus VIP3 is recommended for its superior bromatological composition.
\end{abstract}

Keywords: bromatology, feedlot stages, noncarcass components, weight gain, Zea mays L

\title{
RESUMO
}

O objetivo deste trabalho foi avaliar desempenho, características da carcaça e comportamento ingestivo de novilhos terminados em confinamento alimentados com silagens dos híbridos de milho: Maximus VIP3, Defender VIP e Feroz VIP. O experimento teve duração de 112 dias, sendo quatro pesagens a cada 28 dias. As dietas experimentais foram formuladas e constituídas por silagem de milho e ração peletizada em proporção de 50:50, na base seca. Independentemente do híbrido utilizado, houve aumento conforme avanço na fase de terminação $(9,15 ; 9,14 ; 9,35$ e 9,59kg dia-1, na primeira, segunda, terceira e quarta pesagens, respectivamente). A distinção da silagem de milho determinou diferença no ganho de peso dos animais, com média final de 1,413kg para os animais tratados com Maximus VIP3, 1,375kg para os tratados com Defender VIP e 1,184 para aqueles alimentados com Feroz VIP. Os animais alimentados com silagem do híbrido Feroz VIP apresentaram maior eficiência de ganho de carcaça e foram mais ativos ao número de vezes em ir ao comedouro. Apesar dos três híbridos avaliados proporcionarem bons resultados relacionados ao desempenho animal, as características da carcaça não sofreram alterações; mesmo assim, recomenda-se o híbrido Maximus VIP3 por sua superioridade bromatológica.

Palavras-chave: bromatologia, fases de confinamento, ganho de peso, híbridos silageiros, Zea mays L

Recebido em 21 de setembro de 2018

Aceito em 29 de dezembro de 2018

E-mail: egonhh@yahoo.com.br 


\section{INTRODUCTION}

Genetic improvement has led to the development of more productive maize hybrids, which are better in terms of pest and disease tolerance and are more adapted to different climate and soil conditions. This evolution, which is unquestionable, leads to greater productive efficiency (Neumann et al., 2013). However, questions related only to agronomic performance are insufficient to identify a good hybrid for silage production. With the great number of variable hybrids possessing distinct phenotypic and nutritional characteristics, it is essential to identify which ones offer the best animal response (Neumann et al., 2017). For this reason, genetic improvement companies have been increasingly dedicating themselves to searching for more complete materials for silage production.

It has already been proven experimentally that different hybrids generate silages with different bromatological characteristics (Restle et al., 2006, Pinto et al., 2010, Salazar et al., 2010), but these differences do not normally interfere with animal performance. In contrast, Neumann et al. (2017) indicated a significant difference not only in silage bromatology but also in dry matter intake during different periods and in the final weight gain of feedlot steers.

Restle et al. (2006) describe the importance of the hybrid used when comparing diets consisting of different hybrids. Rosa et al. (2004) also argue that silage composed of different hybrids affects animal performance, and they conclude in same study that the scarcity of information describing the genetic potential of the large number of existing hybrids renders it difficult to select the best material for silage production. Among the authors of existing literature studies involving hybrid comparisons, there is a consensus that it is necessary to study the effects of different genetic materials on animal performance.

The hybrids of maize, Maximus VIP3, Defender VIP and Feroz VIP, are considered genetic materials capable of producing high-quality nutritional silage. However, there is limited information regarding comparisons of animal responses to the silage utilization of these hybrids under the same conditions. The objective of this work was to evaluate performance, carcass characteristics, and ingestive behavior of feedlot steers fed with silages composed of these maize hybrids.

\section{MATERIAL AND METHODS}

The experiment was conducted at the Animal Production Center (NUPRAN) of the Sector of Agrarian and Environmental Sciences at State University of Middle-West (UNICENTRO), in Guarapuava/PR. Samples of silages and concentrate used to feed the animals were weighed and pre-dried in a forced air oven at $55^{\circ} \mathrm{C}$ until a constant weight was obtained to determine the content of partially dried matter, and then, the samples were milled in a "Wiley" knife mill with a $1 \mathrm{~mm}$ mesh sieve. In the predried samples, the total dry matter (DM) was determined in an oven at $105^{\circ} \mathrm{C}$, while crude protein $(\mathrm{CP})$ was determined by the micro Kjeldahl method, and mineral matter (MM) was determined by incineration at $550^{\circ} \mathrm{C}$ ( 4 hours), according to AOAC International standards (Official..., 1995). Neutral detergent fiber (NDF) content was determined using thermostable $\alpha$ amylase (Termamyl 120L, Novozymes, Latin America Ltd.), while acid detergent fiber (ADF), lignin (ADL), lipids and sugars were determined according to the methods of Silva and Queiroz (2009). Starch content was determined according to the methodology described by Poore et al. (1993).

For the performance evaluations, 36 Angus steers were used, which had an average age of 10 months and initial mean live weight of $330 \mathrm{~kg}$ and were dewormed prior to the beginning of the experiment. The present study was approved by the Committee of Ethics on Animal Use CEUA/UNICENTRO on May 27, 2017, official number 002/2017. The experiment lasted 122 days, with 10 days of adaptation of animals to experimental conditions followed by sequential weighing every 28 days. The animals were fed ad libitum twice a day at 6:00 a.m. and 6:00 p.m. The animals were housed in 18 stalls, each capable of accommodating two animals per stall, with a floor area of $15 \mathrm{~m}^{2}(2.5 \times 6.0 \mathrm{~m})$ and each stall containing a concrete feeder measuring $2.30 \mathrm{~m}$ in length, $0.60 \mathrm{~m}$ in width, and $0.35 \mathrm{~m}$ in height, with a metallic drinker regulated by an automatic float. 
The experimental diets were formulated and constituted of maize silage and commercial palletized ration (Cooperativa Agraria Agroindustrial $^{\circledR}$ ) in a 50:50 ratio (dry matter). The following foods were used to make the concentrate: soybean meal, soybean bark, barley radish, ground corn kernels, wheat bran, calcitic limestone, dicalcium phosphate, common salt, animal urea, and vitamin-mineral premix. Table 1 shows the chemical composition of experimental food used in the animal feed.

Table 1. Bromatological composition of maize silage and concentrate used to feed steers

\begin{tabular}{lllll}
\hline \multirow{2}{*}{ Parameter } & \multicolumn{3}{c}{ Hybrid } & \multirow{2}{*}{ Concentrate } \\
\cline { 2 - 4 } & Maximus VIP3 & Defender VIP & Feroz VIP & 88.72 \\
Dry matter & 34.30 & 34.07 & 34.27 & 23.83 \\
ADIde protein & 9.14 & 8.75 & 8.98 & - \\
NDIP & 0.25 & 0.29 & 0.34 & - \\
ADF & $1.05^{\mathrm{b}}$ & $1.16^{\mathrm{b}}$ & $1.48^{\mathrm{a}}$ & 11.15 \\
NDF & 26.54 & 29.23 & 25.85 & 32.00 \\
ADL & $43.71^{\mathrm{c}}$ & $49.07^{\mathrm{a}}$ & $45.54^{\mathrm{b}}$ & 2.44 \\
Ash & 4.96 & 5.12 & 4.94 & 5.88 \\
Lipids & 3.01 & 2.51 & 2.58 & 3.98 \\
Sugar & 3.44 & 2.90 & 3.12 & 3.77 \\
Starch & $4.55^{\mathrm{a}}$ & $4.05^{\mathrm{b}}$ & $3.93^{\mathrm{b}}$ & 31.83 \\
\hline Avarag & $37.27^{\mathrm{a}}$ & $34.33^{\mathrm{b}}$ & $34.09^{\mathrm{b}}$ & \\
\hline
\end{tabular}

Averages followed by different letters in the line differ by the Tukey Test at $5 \%$.

Performance evaluations were conducted by weighing the animals at the beginning of confinement on days $0,28,56,84$ and 112 , under 12 hours of solid fasting. The variables evaluated at these different times were body weight (BW), absolute dry matter intake, expressed in $\mathrm{kg}$ animal day ${ }^{-1}$ (DDMI) or expressed as percentage of body weight (DMIBW), daily weight gain (DWG), and feed conversion (FC). The DDMI was calculated as the difference between the daily amount of food supplied and the amount of food left over from the previous day. The DMIBW was obtained by multiplying the ratio between DDMI and BW by 100. The DWG was calculated by dividing the difference between the final $\left(\mathrm{BW}_{\mathrm{f}}\right)$ and the initial $(\mathrm{BWi})$ of each experimental period by the number of evaluation days during that period, while the FC was obtained by calculating the ratio between the DDMI and DWG.

Total fecal collection was conducted in each experimental feedlot unit for three consecutive days during each evaluation period (Johnson and Combs, 1991) to determine the apparent digestibility of each experimental diet, using the system of equations cited by Silva and Leão (1979). Manure was weighed and sampled at each 6-hour shift and then was stored in a freezer at $-18{ }^{\circ} \mathrm{C}$ until analysis. The food and leftovers from the previous day were also collected. After completing the evaluation period, the samples were thawed and homogenized to form a composite sample corresponding to each experimental feedlot unit. The dry matter content of the food, leftovers, and manure generated within each experimental unit was determined through the same procedures adopted for the food analysis. Data related to the ingestive behavior of animals were collected for three consecutive days (72 hours) during each evaluation period. The animals were observed every five minutes in order to record time spent consuming food and water, lying down and standing while ruminating, and lying down and standing while idle (Missio et al., 2010).

At the end of the full 112 day evaluation period, the animals were subjected to fasting from solids for 12 hours and weighed before shipment to a slaughterhouse. The gain of carcass weight during confinement (WGC; $\mathrm{kg}$ ) was obtained by calculating the difference between the warm carcass weight at the time of slaughter and initial body weight (BWi) of the animals under a theoretical carcass yield of $50 \%$. Based on the 112 day feedlot evaluation period, the mean gain in carcass weight (MCG; $\mathrm{kg} \mathrm{day}^{-1}$ ) was obtained by calculating the ratio between $\mathrm{WGC}$ and BWD. Based on this same evaluation period, we also calculated the efficiency of food transformation in carcass (ETC; $\mathrm{kg}$ of DM kg of 
carcass $^{-1}$ ) and the efficiency of transformation of weight gain in carcass. This latter measurement, expressed as a percentage, was obtained by calculating the ratio between MCG and DWG. For the calculations described, the warm carcass weights were used.

Five measures of development were evaluated in the carcasses: carcass length, which is the distance between the medium-cranial border of the pubic bone and the medium-cranial border of the first rib; leg length, which is the distance between the medium-cranial border of the pubic bone and the tibiotarsal joint; arm length, which is the distance between the tuberosity of the olecranon and the radiocarpal joint; perimeter of arm, obtained in the median region of the arm encircled with a tape measure; and the thickness of the cushion, measured by means of a compass perpendicular to carcass length, taking the greatest distance between the cut that separates the two half-carcasses and the lateral muscles of the thigh, according to the methodologies suggested by Muller (1987).

At the time of slaughter, the characterization of the non-carcass components of the carcass of the steers was also conducted by collecting the weights of the following components: head, tongue, tail, leather, and legs (called external components); and heart, kidneys, liver, lungs, spleen, empty rumen and reticulum, full rumen and reticulum, and full intestines (called vital organs).

For the parameters related to animal performance and characteristics of the carcass, the experimental design was completely randomized and was composed of three treatments with six replicates, where each replicate corresponded to a stall with two animals. The data collected for each variable were subjected to an analysis of variance with a comparison of means at $5 \%$ of significance. The analyses were conducted using the statistical program SAS (1993). The analysis of each variable followed the statistical model: $\mathrm{Y}_{i j}=\mu+\mathrm{T}_{i}+\mathrm{E}_{\mathrm{ij}}$, where $\mathrm{Y}_{i j}=$ dependent variables, $\mu=$ overall mean of all observations, $T_{i}$ $=$ effect of treatments, and $\mathrm{E}_{i j}=$ residual random effect.

\section{RESULTS AND DISCUSSION}

Despite the fact that the Defender VIP hybrid showed higher NDF content (Table 1) and knowledge that dry matter intake is limited to the intake of NDF (Rosa et al., 2004), for the evaluation periods and for the general average of the hybrids, we did not observe significant difference for dry matter intake expressed as percentage of body weight (Table 2). On the other hand, we observed an increase in dry matter consumption ( $\mathrm{kg}$ of animal $\mathrm{day}^{-1}$ ), regardless of the hybrid used, as the feedlot evaluation periods progressed $(9.15,9.14,9.35$ and $9.59 \mathrm{~kg} \mathrm{day}^{-1}$ in the first, second, third and fourth weighing, respectively). This behavior is explained by the increasing energy and protein demands of the animals as they gain body weight (NRC, 2001).

Other than in the first period of the feedlot evaluation, the different maize silages altered the animals' weight gain, with a final mean of $1.413 \mathrm{~kg}$ for animals fed with Maximus VIP3, $1.375 \mathrm{~kg}$ for those fed with Defender VIP, and 1.184 for those fed with Feroz VIP. As there was no significant difference in dry matter intake, it is suggested that the greater weight gain related to consumption of the first hybrid (i.e., Maximus VIP3) is due to its higher nutritional quality (Table 1). Rosa et al. (2004) and Restle et al. (2006) did not observe a significant difference in the weight gain of animals, despite finding qualitative differences among the evaluated hybrids. However, neither of these studies cites the starch concentration of the silages, which is a determining factor for these results. Paziani et al. (2009) corroborate this assumption by reporting that the increase in starch in silage favors a higher digestibility, a statement that is in agreement with the apparent digestibility values presented in Table 3 (70.0\% for Maximus VIP3, $68.7 \%$ for Defender VIP and $68.3 \%$ for Feroz VIP) $(\mathrm{P}=0.0943)$. According to Oliveira et al. (2011), these values are sufficient for providing high animal performance. The values of dry matter and manure production $\left(\mathrm{kg} \mathrm{DM}^{-1}\right)$ reported here are similar to those described by Neumann et al. (2017) when evaluating animals fed in proportions similar to those of the present study, but with different hybrids, demonstrating that these values can be considered standard for this type of diet. 
Table 2. Dry matter intake ( $\mathrm{kg} \mathrm{day}^{-1}$ or per $100 \mathrm{~kg}$ live weight), daily average weight gain, and feed conversion of feedlot steers fed different maize silages, according to evaluation periods

\begin{tabular}{|c|c|c|c|c|}
\hline \multirow{2}{*}{ Hybrid } & \multicolumn{4}{|c|}{ Days in feedlot } \\
\hline & $0-28$ days & $0-56$ days & $0-84$ days & 0-112 days \\
\hline & \multicolumn{4}{|c|}{ Dry matter intake, $\mathrm{kg}$ animal day ${ }^{-1}$} \\
\hline Maximus VIP3 & 9.362 & 9.485 & 9.700 & 9.889 \\
\hline Defender VIP & 9.365 & 9.242 & 9.486 & 9.770 \\
\hline Feroz VIP & 8.751 & 8.704 & 8.891 & 9.139 \\
\hline Average & 9.159 & 9.144 & 9.359 & 9.598 \\
\hline \multirow[t]{2}{*}{$P$} & 0.1839 & 0.2137 & 0.2740 & 0.2987 \\
\hline & \multicolumn{4}{|c|}{ Dry matter intake per $100 \mathrm{~kg}$ of body weight, $\%$} \\
\hline Maximus VIP3 & 2.33 & 2.42 & 2.35 & 2.21 \\
\hline Defender VIP & 2.22 & 2.36 & 2.30 & 2.17 \\
\hline Feroz VIP & 2.16 & 2.16 & 2.21 & 2.10 \\
\hline Average & 2.24 & 2.35 & 2.28 & 2.15 \\
\hline \multirow[t]{2}{*}{$P$} & 0.2206 & 0.1799 & 0.2912 & 0.5238 \\
\hline & \multicolumn{4}{|c|}{ Dry matter intake per unit of metabolic weight, $\mathrm{g} \mathrm{kg}^{-0.75}$} \\
\hline Maximus VIP3 & 11.02 & 10.38 & 9.77 & 9.38 \\
\hline Defender VIP & 11.00 & 10.13 & 9.58 & 9.33 \\
\hline Feroz VIP & 10.40 & 9.72 & 9.25 & 8.98 \\
\hline Average & 10.81 & 10.08 & 9.53 & 9.23 \\
\hline \multirow[t]{2}{*}{$P$} & 0.3472 & 0.4525 & 0.6596 & 0.5905 \\
\hline & \multicolumn{4}{|c|}{ Weight gain, $\mathrm{kg}$ animal day ${ }^{-1}$} \\
\hline Maximus VIP3 & $1.220^{\mathrm{a}}$ & $1.304^{\mathrm{a}}$ & $1.423^{\mathrm{a}}$ & $1.413^{\mathrm{a}}$ \\
\hline Defender VIP & $1.191^{\mathrm{a}}$ & $1.241^{\mathrm{ab}}$ & $1.375^{\mathrm{ab}}$ & $1.375^{\mathrm{ab}}$ \\
\hline Feroz VIP & $0.959^{\mathrm{a}}$ & $1.034^{\mathrm{b}}$ & $1.176^{\mathrm{b}}$ & $1.184^{\mathrm{b}}$ \\
\hline Average & 1.123 & 1.193 & 1.325 & 1.324 \\
\hline \multirow[t]{2}{*}{$P$} & 0.3407 & 0.0901 & 0.0894 & 0.0480 \\
\hline & \multicolumn{4}{|c|}{ Feed conversion (DMI WGD ${ }^{-1}$ ) } \\
\hline Maximus VIP3 & 8.33 & 7.68 & 7.19 & 6.92 \\
\hline Defender VIP & 8.32 & 7.74 & 7.20 & 6.99 \\
\hline Feroz VIP & 9.43 & 8.98 & 8.12 & 7.69 \\
\hline Average & 8.69 & 8.13 & 7.50 & 7.20 \\
\hline$P$ & 0.6493 & 0.1377 & 0.0820 & 0.1106 \\
\hline
\end{tabular}

Averages followed by lowercase letters in the column differ by the Tukey Test at $5 \%$.

Table 3. Production of manure $\left(\mathrm{kg} \mathrm{day}^{-1}\right)$ and apparent digestibility of diets of feedlot steers fed different maize silages

\begin{tabular}{llll} 
Hybrid & Dry matter of manure $(\%)$ & $\begin{array}{l}\text { Manure production } \\
\left(\mathrm{kg} \text { of DM day }{ }^{-1}\right)\end{array}$ & Apparent digestibility $(\%)$ \\
\hline Maximus VIP3 & 17.1 & 2.88 & 70.0 \\
Defender VIP & 17.8 & 2.93 & 68.7 \\
Feroz VIP & 17.6 & 2.81 & 68.3 \\
Average & 17.5 & 2.87 & 69.0 \\
$P$ & 0.3129 & 0.8407 & 0.0943 \\
C.V $\%$ & 4.29 & 12.49 & 3.38 \\
\hline
\end{tabular}

According to Restle et al. (2006), in diets with high voluminous concentrations, the most correct way of expressing intake would be by adjusting it to a unit of metabolic weight. It is observed in Table 2 that the intake per unit of metabolic weight decreased with the advancement of the feedlot evaluation periods but did not differ among treatments. According to Rosa et al. (2004), reductions in intake per unit of metabolic weight with the advancement of feedlot period are expected and result from the maturation of the animals, leading to alterations in weight gain 
through increased depositions of body fat. As the amount of body fat increases, there is a greater competition for abdominal space and a physiological response of the adipose tissue, resulting in the physiological response of reduced consumption. This effect is clear when observing that the thickness of subcutaneous fat also did not vary among treatments (Table 4). Table 4 also shows that the mean values for the body metric characteristics of the animals, carcass length, cushion thickness, arm length, and arm perimeter were not significantly different for animals fed the different hybrids. According to the correlation coefficients between some body metric characteristics and some performance characteristics, the final weight was positively correlated to carcass length $(\mathrm{r}=0.77)$ and arm circumference $(r=0.52)$ and was negatively correlated to arm length. As highlighted by Restle et al. (2006), these results demonstrate that long and low animals are preferred for feedlot evaluations.

Table 4. Carcass characteristics of feedlot steers fed different maize silages

\begin{tabular}{|c|c|c|c|c|c|}
\hline \multirow{2}{*}{ Parameter } & \multicolumn{3}{|c|}{ Hybrid } & \multirow{2}{*}{ Average } & \multirow{2}{*}{$P$} \\
\hline & Maximus VIP3 & Defender VIP & Feroz VIP & & \\
\hline Carcass yield, $\%$ & 54.83 & 55.49 & 55.93 & 55.41 & 0.2686 \\
\hline \multicolumn{6}{|l|}{ Fat thickness, mm } \\
\hline Rear & 6.25 & 5.00 & 5.25 & 5.50 & 0.1715 \\
\hline Rib & 6.33 & 6.50 & 6.50 & 6.44 & 0.1848 \\
\hline . Front & 4.42 & 4.00 & 3.50 & 3.97 & 0.4514 \\
\hline Carcass length, m & 1.26 & 1.26 & 1.24 & 1.26 & 0.2341 \\
\hline Cushion thickness, $\mathrm{cm}$ & 21.00 & 20.42 & 19.83 & 20.42 & 0.2874 \\
\hline Arm lenght, $\mathrm{cm}$ & 38.83 & 38.83 & 38.67 & 38.78 & 0.9623 \\
\hline Arm perimeter, $\mathrm{cm}$ & 40.17 & 40.08 & 40.42 & 40.22 & 0.8802 \\
\hline
\end{tabular}

Regardless of treatment, the values of carcass yield were satisfactory, which, according to Pinto et al. (2010), is attractive to slaughterers. In addition, the yield of non-carcass components is shown to be an extra source of income for the slaughterers; therefore, profitability with animals is increased through good carcass yield and utilization of these non-carcass components (Vaz et al., 2010). The yield values of non-carcass components as a percentage of live weight are shown in Table 5. We did not observe significant differences for heart $(0.32 \%)$, liver $(0.93 \%)$, lungs $(0.74 \%)$, kidneys $(0.21 \%)$, spleen $(0.34 \%)$, rumen and reticulum, full and empty $(6.56 \%$ and $1.70 \%)$, head $(2.15 \%)$, tongue $(0.16 \%)$, leather $(8.90 \%)$, tail $(0.24 \%)$ and legs $(1.94 \%)$, while intestinal weight did show a significant difference $(\mathrm{P}<0.05)$ and was the largest definitive body weight gain for this response (Vaz et al., 2015).

One of the most desirable features of a maize hybrid for silage is high digestibility and/or low indigestible fractions (Mendes et al., 2008), as the latter directly interferes with the carcass weight gain of animals. Because of the similarity among the three evaluated hybrid materials, no significant effect was observed in the average carcass weight gain, with a mean of $0.904 \mathrm{~kg} \mathrm{day}^{-1}$.
As a consequence of the superior weight gain of animals fed with Maximus VIP3 silage, the efficiency of transformation of weight gain in carcass was lower $(\mathrm{P}<0.05)$ than that in animals fed with Feroz VIP silage $(65.3 \%$ versus $72.2 \%$, respectively; Table 6). Neumann et al. (2017) observed similar behavior for the same variables when comparing other maize hybrids. The equivalent carcass gain and the conversion of dry matter intake in the carcass were not significantly different, with a final mean of $101.2 \mathrm{~kg}$ and $10.649 \mathrm{~kg}$ of DM kg of carcass ${ }^{-1}$, respectively.

The ingestive behavior of the experimental steers is presented in Table 7. The time required for feeding had no significant effect, but the number of times the animals went to the feeder varied $(\mathrm{P}<0.05)$ according to the silage provided, even though there was no difference in dry matter intake. We believe that the highest number of trips to the feeder for those animals fed with Feroz VIP silage is due to its higher NDF content (Table 1). This constituent causes filling of the gastrointestinal tract or rumen distention, leading to physical limitations and some discomfort to the animal or some other physiological effect (Silva Freitas et al., 2010). 
Performance, carcass...

Table 5. Yield of non-carcass components (\% of live weight) of feedlot steers fed different maize silages

\begin{tabular}{|c|c|c|c|c|c|c|}
\hline \multirow{2}{*}{ Parameter } & \multicolumn{4}{|c|}{ Hybrid } & \multirow{2}{*}{ Average } & \multirow{2}{*}{$P$} \\
\hline & Maximus VIP3 & Defender & VIP & Feroz VIP & & \\
\hline \multicolumn{7}{|l|}{ Vital organs, live weight $\%$} \\
\hline Heart & 0.36 & 0.32 & & 0.32 & 0.33 & 0.1478 \\
\hline Liver & 1.11 & 0.99 & & 0.93 & 1.01 & 0.2676 \\
\hline Lungs & 0.79 & 0.73 & & 0.70 & 0.74 & 0.0853 \\
\hline Kidneys & 0.23 & 0.21 & & 0.20 & 0.21 & 0.2466 \\
\hline Spleen & 0.35 & 0.35 & & 0.30 & 0.34 & 0.4836 \\
\hline Full rumen and reticulum & 6.93 & 6.56 & & 6.10 & 6.56 & 0.5256 \\
\hline Empty rumen and reticulum & 1.82 & 1.66 & & 1.63 & 1.70 & 0.4563 \\
\hline Intestines & $4.02^{\mathrm{a}}$ & $3.33^{\mathrm{b}}$ & & $3.33^{\mathrm{b}}$ & 3.56 & 0.0204 \\
\hline \multicolumn{7}{|c|}{ External components, live weight $\%$} \\
\hline Head & 2.42 & 2.23 & & 2.15 & 2.26 & 0.0910 \\
\hline Tougue & 0.17 & 0.16 & & 0.16 & 0.16 & 0.0905 \\
\hline Leather & 9.33 & 8.71 & & 8.90 & 8.98 & 0.6928 \\
\hline Tail & 0.26 & 0.25 & & 0.24 & 0.25 & 0.4810 \\
\hline Legs & 2.12 & 1.90 & & 1.94 & 1.99 & 0.2646 \\
\hline
\end{tabular}

Averages followed by different letters in the line differ by the Tukey Test at $5 \%$.

Table 6. Carcass weight gain during confinement (WGC; $\mathrm{kg} \mathrm{day}^{-1}$ ) and during the 112 day feedlot evaluation period (MCG; $\mathrm{kg} \mathrm{day}^{-1}$ ), transformation efficiency of weight gain in carcass (WGC $\mathrm{WGD}^{-1}$ ), and dry matter intake in carcass (ETC; $\mathrm{kg}$ of DM kg of carcass ${ }^{-1}$ ) of feedlot steers fed different maize silages

\begin{tabular}{|c|c|c|c|c|}
\hline Hybrid & $\begin{array}{l}\text { WGC } \\
\left(\mathrm{kg} \mathrm{day}^{-1}\right)\end{array}$ & $\begin{array}{l}\text { WGC WGD }^{-1} \\
(\%)\end{array}$ & $\begin{array}{l}\text { MCG } \\
(\mathrm{kg})\end{array}$ & $\begin{array}{l}\text { ETC } \\
\left(\mathrm{kg} \text { of DM kg of } \text { carcass }^{-1}\right)\end{array}$ \\
\hline Maximus VIP3 & 0.918 & $65.3^{\mathrm{b}}$ & 102.9 & 10.759 \\
\hline Defender VIP & 0.940 & $69.0^{\mathrm{ab}}$ & 105.2 & 10.461 \\
\hline Feroz VIP & 0.853 & $72.2^{\mathrm{a}}$ & 95.6 & 10.727 \\
\hline Average & 0.904 & 68.8 & 101.2 & 10.649 \\
\hline$P$ & 0.2829 & 0.0382 & 0.2804 & 0.7075 \\
\hline $\mathrm{CV}, \%$ & 10.16 & 5.67 & 10.16 & 6.31 \\
\hline
\end{tabular}

Averages followed by lowercase letters in the column differ by the Tukey Test at $5 \%$.

Table 7. Ingestive behavior of steers fed different maize silages

\begin{tabular}{|c|c|c|c|c|c|}
\hline \multirow{2}{*}{ Parameter } & \multicolumn{3}{|c|}{ Hybrid } & \multirow{2}{*}{ Average } & \multirow{2}{*}{$P$} \\
\hline & Maximus VIP3 & Defender VIP & Feroz VIP & & \\
\hline \multicolumn{6}{|l|}{ Hours day ${ }^{-1}$} \\
\hline Feeding & 3.17 & 2.89 & 3.12 & 3.06 & 0.6615 \\
\hline Drinking & 0.28 & 0.27 & 0.25 & 0.26 & 0.1577 \\
\hline Ruminating & 6.43 & 6.21 & 5.85 & 6.16 & 0.5024 \\
\hline Idle & 14.17 & 14.66 & 14.82 & 14.55 & 0.6289 \\
\hline \multicolumn{6}{|c|}{ Number of times day ${ }^{-1}$} \\
\hline Feeder & $15.0^{\mathrm{ab}}$ & $13.1^{\mathrm{b}}$ & $16.6^{\mathrm{a}}$ & 19.9 & 0.0202 \\
\hline Drinker & 7.28 & 7.13 & 6.80 & 7.1 & 0.6576 \\
\hline Urinate & 4.5 & 5.6 & 5.4 & 5.2 & 0.2878 \\
\hline Excrete & 7.3 & 8.1 & 7.4 & 7.6 & 0.7362 \\
\hline
\end{tabular}

Averages followed by different letters in the line differ by the Tukey Test at $5 \%$.

The silages of the different hybrids did not influence the time that the animals spent drinking water, ruminating, or in leisure or the number of times they went to the drinker, or urinated or excreted.

\section{CONCLUSIONS}

Although the Maximus VIP3 hybrid provided silage with a higher nutritive value, the animal performance and carcass characteristics 
remained unchanged. Even so, it is important to recommend hybrids with bromatological superiority.

\section{ACKNOWLEDGMENT}

To the Coordination of Improvement of HigherLevel Personnel (CAPES).

\section{REFERENCES}

JOHNSON, T.R.; COMBS, D.K. Effects of prepartum diet, inert rumen bulk, and dietary polythylene glicol on dry matter intake of lactating dairy cows. J. Dairy Sci., v.74, p.933-944, 1991.

MENDES, M.C.; VON PINHO, R.G.; PEREIRA, M.N. et al. Avaliação de híbridos de milho obtidos do cruzamento entre linhagens com diferentes níveis de degradabilidade da matéria seca. Bragantia, v.67, p.285-297, 2008.

MISSIO, R.L.; BRONDANI, I.L.; ALVES FILHO, D.C. et al. Comportamento ingestivo de tourinhos terminados em confinamento, alimentados com diferentes níveis de concentrado na dieta. Rev. Bras. Zootec., v.39, p.1571-1578, 2010.

MULLER, L. Normas para avaliação de carcaças $e$ concurso de carcaça de novilhos. 2.ed. Santa Maria: Universidade Federal de Santa Maria. 1987. 31p.

NATIONAL RESEARCH COUNCIL - NRC. Nutrient requirements of dairy cattle. Washington, D.C.: National Academy of Science, National Academy Press, 2001. 381p.

NEUMANN, M.; HORST, E.H.; SOUZA, A.M. et al. Desempenho de novilhos confinados alimentados com silagens de diferentes híbridos de milho. Rev. Bras. Milho Sorgo, v.16, p.524-535, 2017.

NEUMANN, M.; MARAFON, F.; UENO, K.R. Eficiência de confecção da silagem de milho: processamento de grãos e tamanho de partícula. Inf. Agropecu., v.34, p.7-18, 2013.

OFFICIAL methods of analysis. 16.ed. Washington: AOAC, 1995. 2000p.

OLIVEIRA, M.R.; NEUMANN, M.; MENDES, M.C. et al. Resposta econômica na terminação de novilhos confinados com silagens de milho (Zea mays L.), em diferentes estádios de maturação, associadas a dois níveis de concentrado na dieta. Rev. Bras. Milho Sorgo, v.10, p.87-95, 2011.

PAZIANI, S.F.; DUARTE, A.P.; NUSSIO, L.G.; BOLLER, P. Características agronômicas e bromatológicas de híbridos de milho para produção de silagem. Ver. Bras. Zootec, v.38, p.411-417, 2009.
PINTO, A.P.; ABRAHÃO, J.J.D.S.; MARQUES, J.D.A. et al. Performance and carcass characteristics of crossbred young bulls finished in a feedlot on diets with sorghum silage substituted by sugar cane. Rev. Bras. Zootec., v.39, p.198-203, 2010.

POORE, M.H.; MOORE, J.A.; ECK, T.P. Effect of fiber source and ruminal starch degradability on site and extent of digestion in dairy cows. J. Dairy Sci., v.76, p.2244-2253, 1993.

ROSA, J.R.P.; SILVA, J.H.S.; RESTLE, J. et al. Avaliação do comportamento agronômico da planta e valor nutritivo da silagem de diferentes híbridos de milho (Zea mays, L.). Rev. Bras. Zootec., v.33, p.302312. 2004.

RESTLE, J.; PACHECO, P.S.; ALVES FILHO, D.C. et al. Silagem de diferentes híbridos de milho para produção de novilhos superjovens. Rev. Bras. Zootec., v.35, p.2066-2076, 2006.

SALAZAR, D.R.; STABILE, S.D.S.; GUIMARAES, P.D.S. et al. Valor nutritivo do colmo de híbridos de milho colhidos em três estádios de maturidade. Pesqui. Agropecu. Bras., v.45, p.758-766, 2010.

SAS INSTITUTE. SAS/STAT user's Guide: statistics, version 6. 4.ed. North Caroline. 1993. 943p.

SILVA, D.J.; QUEIROZ, A.C. Análise de alimentos, métodos químicos e biológicos. 3.ed. Viçosa: Universidade Federal de Viçosa. 2009. 235p.

SILVA FREITAS, L.; SILVA, J.H.S.; SEGABINAZZI, L.R. et al. Substituição da silagem de milho por silagem de girassol na dieta de novilhos em confinamento: comportamento ingestivo. Rev. Bras. Zootec,. v.39, p.225-232, 2010.

SILVA, J.F.; LEÃO, M.I. Fundamentos de nutrição de ruminantes. Piracicaba: Livro Ceres, 1979. 384p.

VAZ, F.N.; RESTLE, J.; ARBOITTE, M.Z. et al. Fatores relacionados ao rendimento de carcaça de novilhos ou novilhas superjovens, terminados em pastagem cultivada. Cienc. Anim. Bras., v.11, p.53$61,2010$.

VAZ, F.N.; RESTLE, J.; PÁDUA, J.T. et al. Componentes não carcaça de bovinos nelore abatidos com diferentes pesos. Cienc. Anim. Bras., v.16, p.313-323, 2015. 